Article

\title{
Trends in the Fashion Industry. The Perception of Sustainability and Circular Economy: A Gender/Generation Quantitative Approach
}

\author{
Patrizia Gazzola ${ }^{1, *(D)}$, Enrica Pavione ${ }^{1}$, Roberta Pezzetti ${ }^{1}$ and Daniele Grechi ${ }^{2}$ (I) \\ 1 Department of Economics, University of Insubria, 21100 Varese, Italy; enrica.pavione@uninsubria.it (E.P.); \\ robertarita.pezzetti@uninsubria.it (R.P.) \\ 2 Department of Human Sciences and Territorial Innovation, University of Insubria, 22100 Como, Italy; \\ grechi.daniele@uninsubria.it \\ * Correspondence: patrizia.gazzola@uninsubria.it; Tel.: +39-0332-395529
}

Received: 16 March 2020; Accepted: 31 March 2020; Published: 2 April 2020

\begin{abstract}
The significant changes which have occurred in the competitive scenario in which fashion companies operate, combined with deep transformation in the lifestyles of final consumers, translate into the need to redefine the business models. Starting from a general overview of the emerging trends today affecting the fashion industry, the paper will devote particular attention to the analysis of the most important phenomena that are influencing this market and the drivers for long-lasting competitiveness: sustainability and attention to the so-called circular economy. According to the literature, from the consumer behavior's point of view, the younger generations are paying growing attention to these issues. In light of these considerations, this paper aimed to analyze how sustainability and circular economy principles are influencing the perception of the fashion world among the new generations of consumers. After mapping the emerging trends in the fashion industry and analyzing the role of sustainability from both the demand and supply side, this paper presents the results of a survey conducted through an anonymous questionnaire made in collaboration with Insubria University. The results of the survey describe the students' behaviour as regards fashion's emerging trends, with particular attention to sustainability issues and the application of circular economy principles. The survey results were analyzed from both a descriptive and quantitative point of view with the aim to check the different perceptions as regards sustainable fashion and circular economy in fashion, focusing mainly on the so-called Generation Z. The results of the analysis proved to be consistent with the theoretical framework and confirm the relevance of sustainability issues in the fashion industry today in driving the demand of Generation Z, by considering a gender perspective. Moreover, the circular economy is descriptively analyzed with the aim to understand the relevance of the different facets for the entire sample of respondents.
\end{abstract}

Keywords: fashion industry; trends; circular economy; sustainability; young generations

\section{Introduction}

The fashion industry is a global business of 1.3 trillion dollars, which employs more than 300 million people worldwide [1] and represents a significant economic force and a substantial driver of global GDP [2]. This industry operates in a highly competitive market dominated by the presence of global brands. In recent times, despite the deep financial crisis of the last decade, the fashion industry has attained fast growth and has experienced vast transformations. According to the market analysis provided by some of the main international consultancy companies (McKinsey, Deloitte Group, BCG), fashion companies today are operating in a very dynamic competitive environment, dominated by 
sudden changes and increasing uncertainty. In a framework dominated by a global increase of life age, thanks to progress in the medical sector and other causes, the fashion industry today has the opportunity to serve both young and old generations at the same time; this factor translates into the need to diversify both business strategies and marketing approaches in order to satisfy the needs of retired consumers and millennial ones. Uncertainty is driven by geopolitical and economic instability, which have affected the market since the 2008 economic and financial crisis. In 2019 data from the World Bank, the International Monetary Fund (IMF) and the Organisation for Economic Co-operation and Development (OECD) forecast a slower growth of the industry in developed markets and a flat growth curve in developing countries. The areas most affected by this trend are Europe, Middle East, and Latin America. Due to the increase of economic uncertainty and political instability, the level of spending for fashion products is declining and, at the same time, the demand for customized and personalized fashion, at lower prices, is expected to grow in the future years. In addition to political instability, other problematic events have characterized the last few years: terrorist attacks, natural disasters, new epidemics, a combination of factors that are not only devastating for the people they directly affect, but also have major consequences for companies and the local communities in which businesses are rooted.

Another important change in the competitive scenario is the growing digitalization of the economy [3,4]. The fashion industry is more and more interconnected with the digital world. Digital platforms and digital marketing strategies are becoming prevalent in the fashion market and many new brands have emerged with the development of e-commerce, which allows companies to engage consumers through virtual reality. According to McKinsey [1], a big increase in online sales is expected in the future with respect to total sales; this trend particularly affects the fashion luxury segment, which is expected to represent about $13 \%$ of the total fashion market in 2020. In recent years, the fashion industry has also experienced an improvement in relationships with existing clients through marketing and digital promotion, rather than expansion through geographic channels and store network expansion [5,6]. Most fashion executives see investments in Information and Communications Technology and the digitalization of the value chain as big opportunities $[7,8]$. Technological investment becomes strategic as the fashion market experiences a growing speed of fast fashion trends. Technology improvement in the production process can provide new opportunities for business, like an acceleration of the life, robust reduction in labor costs, an increase in margins, along with the localization of materials/products (for example, digitalization of inventory), and also increase the sustainability of processes $[9,10]$. Data provided by the International Labor Organization (ILO) estimate that, within a few decades, more than half of all salaried workers (especially in emerging countries, where labor force in the industry is concentrated), will be displaced by automation techniques and advanced technologies in the fashion industry, as in other manufacturing based sectors too. Agile businesses are usually more stable and dynamic, because the mix between employee empowerment, development sprints, and the ability to bring solutions rapidly to customers can help a company become more efficient [11]. Agility requires fashion companies to build flexible supply chains and delivery models able to respond quickly when the environment changes. Disruptions and instability are situations that are not going to stop. Successful fashion companies, in front of uncertainty in the competitive scenario, are acting flexibly to ensure that customer needs are met as a primary objective. To be dynamic is becoming strategic to survive in the long-term and this implies the need for companies to update technologies and to interpret the new trends and to identify how these challenges can be translated into marketing opportunities. As markets and consumer behaviours become more and more sophisticated every year, a successful company must be an "agile" organization, as they cannot delay decisions. In this highly competitive context, the fashion market is becoming more and more concentrated: this phenomenon is reflected with the increasing growth, on the one hand, of mergers and acquisitions activities and, on the other hand, of strategic partnership agreements [12]. The creation of big conglomerates makes fashion industry brands feel more comfortable and less uncertain about the challenges of the global market. Alongside changes in the competitive environment 
in which fashion firms operate, consumer behaviour and preferences continue to evolve rapidly; this requires companies to adapt rapidly to emerging trends by focusing on product innovation and by developing new designs for creating new fashion trends [13,14].

In particular, the most important changes affecting fashion demand can be summarized as follows:

Attention to sustainability and circular economy. Sustainability has recently become an important new driver in consumers' purchasing decisions. Phenomena such as the global population growth, climate change, and land and water scarcity have intensified in recent years and sustainability pressures related both to product and production processes became more relevant in this industry $[15,16]$. The speed of fast fashion, which has emerged in recent years as a new phenomenon with great impacts on the industry, amplifies problems, as it is causing high water consumption, high discharge of hazardous chemicals, an increase in waste, an increase in violations of human rights, together with bigger greenhouse gas emissions. Consumers are expecting transparency more and more across the entire value chain; they want to have more information about both the provenience of goods and the quality of materials used. Brands are responding to these challenges which have arisen from the demand side by trying to be more transparent, in many cases specifying the costs of materials, the mark-up, the costs of labor, transport, duties, and so on. Many cross-industry initiatives have helped companies to identify more sustainable work practices across the product life cycle and several brands have publicly fixed sustainability goals and set standards for imports of fabrics, and they are promoting initiatives for improving innovations in the materials used for producing fashion items.

Online shopping. Statistic ranks available on the Statista.it platform provide the most popular online shopping categories worldwide, sorted by share of internet users who have purchased products from selected categories online. According to this source, in $201857 \%$ of global internet users purchased online fashion-related products. In recent years, online platforms have continued to grow and have become increasingly important in the fashion industry [10]. Many platforms, like Zalando, Amazon, and Myntra, already operate in the fashion industry with their own private label fashion offerings. Online platforms are supposed to grow also in both premium and luxury segments; in this context, fashion companies are trying to improve the customer experience and to increase the quality and variety of services offered. Increasing the importance of online shopping for mass market and luxury fashion items has forced fashion brands to collaborate with online platforms [10,16,17]. Most traditional fashion companies are still skeptical about making collaborations with online giant e-commerce players, because they are scared to lose some control over their brand/company. When brands agree on a partnership with online platforms, there is the need to sign conditions that can benefit both parties. Fashion companies cannot ignore e-commerce anymore and having a partnership with big online players could be a good way to survive in the market and increase the possibility to sell items in more countries, strengthening brand awareness at the same time.

Fast fashion. Competitive pressures are becoming higher and global demand continues to ask for new collections rapidly. Changing collections about every three weeks has induced consumers to act with a new behavior called "see now-buy now". Collections and new fashion items are not only seasonal brought to market, but increased during the year. The New York Times used the expression "fast fashion" for the first time at the end of 1989, when Zara opened a shop in New York; according to this source, a garment produced by Zara would take 15 days to move from the mind of a stylist to the sale of the product itself in a store. Fast fashion is an economic phenomenon that has allowed everyone to dress following the latest trends [17]. In the last twenty years spending little to dress well and in a different way has become the norm for most people, and this is the reason driving the success of the "fast fashion" trend, that is rapidly becoming present in every market [18]. Customers love to see different products every week/month in their favorite stores and this has led to an increase in the demand for new fashion collections over a smaller period of time. This practice has also, on its negative side, increased pressure and strain on the creativity of designers. At the same time, the production rhythms imposed on companies following this trend are only sustainable, from a production viewpoint, 
by delocalizing the production in countries where labor costs are low and where it is therefore easy for workers to be exploited.

Personalization. During the last few years, consumers have become more squeamish and more demanding, they always have high expectations for quality products, customization experiences, and instant assistance at low prices. Consumers choose fashion items according to their values and their personal style [14]. For this reason, fashion companies have to understand how to offer products and experiences that customers will perceive as unique. Many fashion companies have answered to this trend by enlarging their product portfolio and becoming more and more "multistyle brands". This solution can work well, but sometimes the company has to think about what is the difference that makes the product of a brand unique for both customers and competitors [14,17]. A wrong choice can rapidly destroy the brand reputation; this is why brand diversification cannot be the only optimal solution.

Use of artificial intelligence. This technological solution help into turn large and diverse datasets into enriched information that can be used by companies to improve the entire supply chain, starting from design to manufacturing, sales, and advertising $[19,20]$. Artificial intelligence is largely used to understand consumers' preferences. This helps companies with advertising to reach people who have demonstrated (for example, through web researches or number of clicks) interest in a special type of product and allows customization of advertisements and personalization of promotions. In this way, potential customers will receive advertisements on products and services that the artificial intelligence algorithm realizes they were searching, or even complementary ones.

Importance of social media and influencers. One of the main trends in developing e-commerce is social commerce-that is, the use of social media, which supports social interactions, and the contribution of users to assist the sale and purchase of online products and services [21]. This phenomenon is at the beginning of its diffusion, all its potential is thus still to be discovered and analyzed [22]. Social media, such as Facebook, Twitter, Youtube, blog, wiki, and the many other social platforms, has proliferated in these last years, allowing businesses to develop a real social media strategy to exploit the enormous potential provided by these channels. Moreover, while in this period of economic crisis the channel of fashion and traditional apparel is undergoing consistent declines, the fashion and online apparel industry is the one that marks the biggest growth with regard to e-commerce sales. A multichannel strategy is no longer seen by companies as a simple means to sell more, but as a useful tool for managing the relationship with the customer, putting at its disposal as many options to follow them in their purchase $[23,24]$. Multichannel is an increasingly complex phenomenon involving the client at home and in all its movements on different platforms (PC, Tablet, Smartphone, etc.). If the search engines play a particular part in the search for the information, social networks play a strategic role in the post-sales phase. In the social media era, the fashion industry is experiencing the growing role of influencers, as consumers perceive their lifestyle as more authentic and attractive than traditional advertisements [24,25]. Influencers are perceived as near to the common people because they are not models and are not forced to make a campaign, but wear what they like and what fits well on their body; they also show their outfits during a common day in common situations [25]. This important choice does not take into account only the number of followers, but above all the fundamental ability to involve their readers (customer engagement) by inviting them to leave comments, opinions, and likes, together with the ease of being able to gain new followers in a given period. Strong brands that are able to compete successfully in the market today are characterized by rapid growth, social media influence, and e-commerce focused distribution.

Smartphone obsession. According to data from McKinsey and the BoF Fashion Survey of 2018 and 2019, mobile data traffic has surpassed desktop traffic and half of the young generation called "millennials" spend more than three hours every day on their personal smartphones [26,27]. This trend forced many fashion companies to create apps for mobile phones, where customers can visit the website adjusted for mobile devices and buy online directly from the smartphone. As consumers every 
year discover the convenience of using their mobile phones for transactions, mobile payments are also growing fast.

Less importance attached to ownership. Today, consumers express a desire to take advantage of a variety of items and models, placing increased attention on sustainability and affordability of sources. More and more consumers prefer to rent clothes rather than buy them [28,29].

Among the aforementioned changes, the attention to sustainability has undoubtedly been one of the most important trends in the last recent years [30]. Closely connected to the theme of sustainability is that of circularity: new initiatives based on a circular economy have arisen recently in the global market [31,32]. For example, the Ellen McArthur Foundation has created the "Circular Fibers Initiative", which has been the beginning of sensibilization to the circular economy for textiles. Their initiative promotes a transition from the traditional production system to renewable energy sources; the circular model builds economic, natural, and social capital based on three principles: minimize waste and pollution, keep products and materials in use (circular system), regenerate natural systems. In the next section the new trends of the fashion market in terms of sustainability and circular economy will be examined, in order to carry out an in-depth analysis on the perception that the new generations have of these issues in relation to the fashion world. In fact, more and more young consumers are proving to be highly sensible to social and environmental issues and their shopping habits are influenced by those principles. The fashion market is showing the growing tendency of young consumers to follow brands that show attention to these themes, avoiding others [33].

In this framework, the aim of this paper is to offer first an embryonic deepening, susceptible to further investigations, on a current topic but currently little investigated by managerial literature. The growing attention that consumers and, in particular, the younger generations, assign to issues of sustainability and the circular economy, is in fact reflected in the strategies and business models of fashion companies, leading to a redefinition of sectorial boundaries. This perspective opens up interesting research perspectives for management scholars, in particular for marketing and business strategy studies.

\section{The Importance of Sustainability and Circular Economy for the Fashion Market in a Gender Generation Perspective}

\subsection{Sustainability and Circular Economy}

Sustainability has long been at the center of both scientific and institutional debate. Awareness of the need for a change in the sustainable development approach was reaffirmed in the 2030 Agenda. The Agenda is a program of rules, binding the governments of the member countries in respecting people and more properly our planet. It gathers 17 objectives, the so-called Sustainable Development Goals (SDGs) for sustainable development, with 169 goals to be reached by 2030, the deadline within which nations must have met standards for achieving goals [34]. The document in which the 2030 agenda is contained takes the name of Transforming Our World and focuses on the three pillars of sustainable development: economic growth, social inclusion and, environmental protection $[35,36]$. Hák, Janoušková, and Moldan [37] argued that the achievement of sustainability objectives is extremely important for achieving a qualitatively better standard of living. The commitment that each State will have to implement this goal is extremely important and necessary for the common good of today and tomorrow. Taking into account at the same time, and in a balanced way, the three dimensions that are traced in the 17 objectives-namely, economic, social, and ecological development-will have to change the vision and politics of each State [38]. This approach inevitably involves the transition from a linear industrial system to a circular system that can be enabled by the introduction of a new business model, a product manufacturing cycle with a view to both economic and environmental sustainability [39]. Optimization of resource consumption, reduction of energy waste, and reduction of waste are the possibilities in terms of saving capital and resources, with an impact on the environment both inside the company and outside. Circularity subverts traditional business models, leading companies to focus on managing resources within markets rather than in production alone. Businesses are driven to focus 
on what is truly valuable for customers [40]. The circular economy, therefore, becomes a paradigm that balances economic development with the protection of the environment and resources.

The circular economy is very topical and is attracting the attention of both scholars and institutions [41,42]. It is a multidisciplinary issue, which literature is addressing from different points of view [43-46].

According to the classical definition [47-49], a circular economy is an economy designed to be able to regenerate itself, using two types of materials: those organic or renewable, designed to be reused and re-entered at the end of their life cycle in the biosphere, and technical or non-renewable ones, designed to switch cyclically from production to consumption with a minimum loss of quality or value. As an alternative to the linear model of industrial economy, where a resource is used and the deficit discarded, the vision of mass consumerism is undermined in the circular economic system through ever new production factors [50,51]. Reuse and recycling act as starting points to avoid major waste of resources, thus reducing the consequent negative externalities on the external environment [52]. Contaminations, pollution, but also conflicts for the control of supplies have characterized the history of industrialization. As a consequence, circular economy and the sustainability approach are the basis for generating long-lasting benefits by guaranteeing an economic system capable of creating lasting growth, originating income and work for sustenance [53,54]. Sustainability and circular economy impact all sectors of the economy and the fashion world is strongly affected by these new approaches to economic development. Historically, the fashion industry has been associated with excessive consumerism, extremely high costs, elitism, or guilty pleasures. In recent years, sustainability has been one of the most important trends affecting this industry, as already discussed in the previous paragraph [55]. Some data are useful to clarify this point. As previously analyzed, the fashion industry represents a business with a global turnover of 1.3 trillion dollars and it employs more than 300 million people worldwide. Cotton production represents almost $7 \%$ of all jobs in some low-income countries [1]. At the same time, the fashion industry uses more than 98 million tons of non-renewable resources annually, including oil to produce synthetic fibers, fertilizers for cotton plantations, and chemicals for producing, dyeing, and finishing fibers and fabrics. To these, 93 billion cubic meters of water are added, that contribute to worsening the events of drought, the emission of about 1.2 billion tons of $\mathrm{CO}_{2}$, and 500 thousand tons of microplastic fibers poured into the oceans. The social effects are dramatic: employment in the textile sector in underdeveloped countries is often synonymous with low wages, exaggerated working hours, child labor, and slavery conditions. Until the seventies of the last century, in a context in which environmental concerns began to take on importance, fashion firms limited themselves to interpreting sustainability in a communicative key, mainly through green marketing initiatives. It is only from the 1990s that sensitivity towards environmental and social problems has taken on a new value, not only communicative, but above all anchored to the actual productive and organizational capacity of companies [56]. The attention to sustainability, including all those interventions of attention to the territory and the community in which the company operates, respect and protection of the environment, enhancement of human resources, safety of working conditions and protection of health [53], have thus become fundamental drivers for the development of the fashion industry $[15,16,57]$. In a broader sense and in a strategic key [58,59], the concept of sustainability embraces the search for well-being, for a better quality of life and a sense of responsibility towards the community [60]. In an environmental scenario in which the "well-being" variable increasingly becomes a measure of the wealth that a production system is capable of expressing, the attention to sustainability goes in the direction of behaviors that do not end in ethical responsibility and in compliance with regulations, but takes on strategic significance [11]. The approach to sustainability, in fact, impacts the entire value chain, from the commercial proposal to the relationship with the final consumer, up to the management of the end-of-life of a product, within a network gradually more extensive and complex. Empirical evidence shows that the best-performing companies in terms of sustainability are those capable of integrating it into governance processes and in rethinking business models, with the aim of seizing the growth opportunities that a sustainable approach brings with 
it [61]. At the same time, compulsive fashion shortens the average life of a dress: the average number of times a garment is worn before disposal has decreased by $36 \%$. In China this value is about $70 \%$ [62]. The other novelty concerns the raw material used to produce fashion items in terms of type of fiber: polyester has scaled cotton, becoming the most used fabric since the beginning of the twenty-first century. Garments made of $100 \%$ polyester are relatively easy to reconvert into reusable materials [63]. In parallel, the use of mixed fibers, cotton-acrylic or cotton-elastane, are very difficult to recycle and therefore end up swelling the already filled undifferentiated dumps of the world [64]. Very different is the case of mixtures with natural fiber, for example, cotton and polyester. These mixes, to date, are essentially non-recyclable due to the fact that these two components cannot be separated at low cost [63]. Some countries, like the Philippines and India, have closed the imports of second-hand clothes, in order to protect the local textile industry [64]. On the other side, South Africa government allows the import of second-hand clothing only for charitable issues and not for commercial resale [65].

Finally, it is important to remember that in 2009 the Copenhagen Fashion Summit launched the first sustainability program for fashion companies. In fact, for the first time a report guide has been published on sustainability issues addressed to fashion company CEOs. The CEO's Agenda was published in partnership with famous fashion brands and defined Seven Priority Actions useful to have a higher sustainability inside the industry: supply chain traceability, saving water, energy and chemicals, workers' security and respect, sustainable material mix, circular fashion system, better wage systems, digital revolution. The goal of the CEO's Fashion Agenda is to encourage fashion leaders to drive their design and product development teams to create durable products, favoring disassembly of fibers and realizing recyclable garments. On the other side, retailers are incentivized to increase the presence of collections of used garments. Leading fashion companies are encouraged on the one hand to collaborate with governments to develop better circular systems, and on the other hand to develop innovative technologies that can transform textile waste into high-quality fibers. The fashion industry is still far away from being a circular system, where materials are designed and recycled in order to generate "additional value" rather than "additional waste". Many pioneers' companies are exploring "circular models" but, unfortunately, it is a slow transition due to regulatory deficiencies, logistical problems, a lack of technical and economic resources, and a lack of comprehensive solutions as well as adequate infrastructure.

In this scenario, affluent millennial consumers want their preferred fashion brands to be involved and provide a positive contribution to their ecosystem with practical actions and are willing to pay a premium price for those products that come from sustainable brands. In fact, since they value transparency and authenticity, they expect the brands that they buy to reflect their own values. The new affluent generations are more socially and environmentally conscious, and so have higher expectations of fashion brands to be more sustainable and ethical in their production processes. This implies an important lesson for fashion brands that want to attract and retain this market segment: brands need to evolve towards new business models based on ethical, sustainable, and circular fashion $[64,66]$.

\subsection{Gender/Generation Features}

In the context of sustainability, with reference to the fashion sector the analysis of the concept of generation related to gender assumes importance and will be relevant for the description of the survey, the detection of the hypothesis, and the subsequent descriptive and statistical analysis. Usually, it is useful to define the concept of "generation" when there is the necessity to indicate that being born in a certain period and having lived the crucial years of formation in a given cultural climate, characterized by particular historical events, leaves a trace on the ways of feeling, thinking, and acting of individuals [67]. It can be useful to remember that there are five different generations working at the same time $[67,68]$. Generation X: born between 1965 and 1979, they represent 33\% of the workforce, for them it is important that the career is well balanced with private life. In adulthood they assisted the birth of the first computers and are pioneers of technological revolutions in the communication field [67,69]. Generation Y or Millenials: born between 1980 and 1994, they are now the highest group 
of people at work and represent $35 \%$ of the total work force. They are usually represented as "the first digital natives" and they are smart with all available technologies, being able to use also devices in a multitasking way [70]. They are extremely focused on improving themselves and acquiring new professional skills, always trying to reach new goals [69,70]. Generation Z: born after 1995, they live in an era of economic crisis and technological evolution. They have an eight-second attention threshold in which they are able to decide what is interesting and what is not for them. Generation $\mathrm{Z}$ is now entering the labor market and will radically change the way of doing business, both as regards the approach to work and as consumers [71,72]. Regarding the role of gender and sustainability in driving consumer demand, a wide number of previous works [72-76] have highlighted the main features of this phenomenon with regard to different sectors and fields (e.g., food products, education, mobility, and entrepreneurship). The most relevant and consistent results argue that women, especially in the age group between 18 and 34 years, with a higher qualification and an occupation as a student, employee, or teacher, are on average more informed, aware, and passionate than men with regard to the applications of sustainability principles in various fields. Moreover, numerous studies have shown that women's high sensitivity and strong sense of female altruism can influence the gap between men and women, but a recent American study showed that there may be a further reason [77-79]. One of the most significant results is certainly from the work of Brough, Wilkie, Ma et al. [79], which revealed the existence of a psychological connection between sustainability and femininity. Men tend to avoid eco-friendly behaviors and lifestyles because they are judged as un-feminine. With regard to the relationship between fashion, generation of belonging, and sustainability, it is important to point out that, following the PricewaterhouseCoopers (PwC) report "Millennials vs Generation Z" [80], the custodians of this green conception of fashion are Millennials and Generation Z. Respondents make quality one of the prerequisites for the purchase-with six out of 10 people preferring the quality of the garments and accessories purchased over the price-and prefer to buy sustainable products $(37 \%)$ with the desire (not all, but many) to spend more to buy a responsible product. The data, based on a sample of 2424 respondents, of which 39\% were born between 1980 and 1994 (Millennials) and 63\% were born between 1995 and 2010 (Generation Z), show that it is precisely the youngest who are willing to face an increased price tag for a responsible product. The opinions of under-38s are one of the indicators that fashion companies must pay attention to in order to develop an effective long-term strategy [81]. Today, young people represent $30 \%$ of luxury buyers and between now and 2025 they will cover over $45 \%$ of total purchases [82]. In addition, the share of Millennials who have invested in a company (not only in the fashion sector, but overall) committed to sustainability continues to grow: between 2015, when it stood at a share of $17 \%$, and 2018, the value more than doubled, reaching $37 \%$ [82]. On the other hand, the aspirational share is down: today, $40 \%$ of Millennials would like to invest in a sustainable company, compared to $52 \%$ in 2017 [83].

Considering the macrotrends analyzed in the first part of the work and these social and generational characteristics, the following hypotheses will be tested:

- $\quad \mathrm{H} 1$ : Is there a difference between the general fashion sustainability propensity among females and males of the sample, referring to Generation $\mathrm{Z}$ ?

- H2: Is there a difference between the sectorial fashion sustainability (animal welfare, ethical wages, environmental impact) among females and males of the sample, referring to Generation Z?

- H3: Considering the entire sample, is there a difference between the general fashion sustainability propensity among Generation $Z$ and the other part of respondents (i.e., Generations $X$ and $Y$ and baby boomers)?

- Descriptive Research Question (DRQ) 1: From a descriptive point of view, relating to the circular economy questionnaire results, which are the most relevant features for the respondents about this phenomenon? 


\section{Materials and Methods}

To collect these data, a mixed method approach was used $[84,85]$ and the participants were selected using some digital tools, such as email, social media (Facebook, Instagram), and Whatsapp. The entire sample of respondents was considered, excluding the uncompleted responses (for this motivation 35 questionnaires were not considered). The research was conducted from September 2019 to December 2019. The methodology used is applicable when there are both qualitative and quantitative data to collect and analyze, with an integration of distinctive methodologies. The survey was created using Google Module, a useful and free tool to create and manage surveys, questionnaires, multiple-choice tests, quizzes, and much more. Some questions were elaborated using the five-point Likert scale [86]. The questionnaire was totally anonymous, and the results describe the behavior of respondents about fashion matters, from their preferences in buying to the discarding of clothes. The sections of the questionnaire were elaborated on by the authors and were based, in certain cases, on previous surveys [87-89].

Participants were invited to complete a form concerning the following topics, divided in five blocks:

1. General information from respondents;

2. Fashion product characteristics;

3. Online Shopping;

4. Circular economy;

5. Sustainable fashion.

Moreover, due to the target of the work, the exact age factor was employed, instead of the generational terms Millennials or Generation Y, Generation X, and Generation Z, in order to identify the relevant part of the respondents for the subsequent analysis. In this way it was possible to correctly divide the sample into different age groups. From a methodological point of view, for the description of the sample and for testing, DRQ1 (Descriptive Research Question 1) was used as the instrument of descriptive statistics. It is a set of techniques used to describe the basic characteristics of the data collected in an experiment/study [90]. It provides a simple summary, through some techniques, of the sample and the measurements collected. Together with simple graphical analysis, it constitutes the initial starting point for any quantitative data analysis [91]. The hypothesis testing technique was used for testing the other three hypotheses. This technique is employed for data analysis and inference, and it is considered one of the most reliable statistical tools [92], and it is usually employed to test economic and social phenomena [93].

For testing our three hypotheses, two kinds of tests were used.

For testing H1 and H3 the Z-test was used. This test is a parametric statistical test used to verify whether the average value of a distribution differs significantly from a certain reference value $[94,95]$. With respect to the data normality and respecting the assumption for the parametric tests, it was possible to verify if there was a gender difference in the level of sustainability in the fashion for the Generation Z (H1) and if there were different levels of fashion sustainability (H3) between Generation $\mathrm{Z}$ and the other respondents (Generation $\mathrm{X}, \mathrm{Z}$, and Baby Boomers).

The second Hypothesis (H2) was evaluated with the Chi-Squared Test of Independence. In this case, two casual variables are described as independent if the probability distribution of one variable is not influenced by the presence of the second [92-94]. By using this tool, the aim was to test if there was a relationship between the sex and the specific level in the fashion sustainability. This hypothesis was made by three tests (related to the same sample) that evaluated the following aspects: ethical wage, environment, and animal welfare.

\section{Results}

From a descriptive point of view, the number of final respondents was 1238; considering gender, the sample was made up of $70 \%$ women and men for the remaining $30 \%$. 
In order to better differentiate the different generations, respondents were also asked to indicate their age. The great majority were young people (16-25 years old, Generation Z), which represented $83 \%$ of the total sample. The following graph (Figure 1 ) shows the age distribution among respondents.

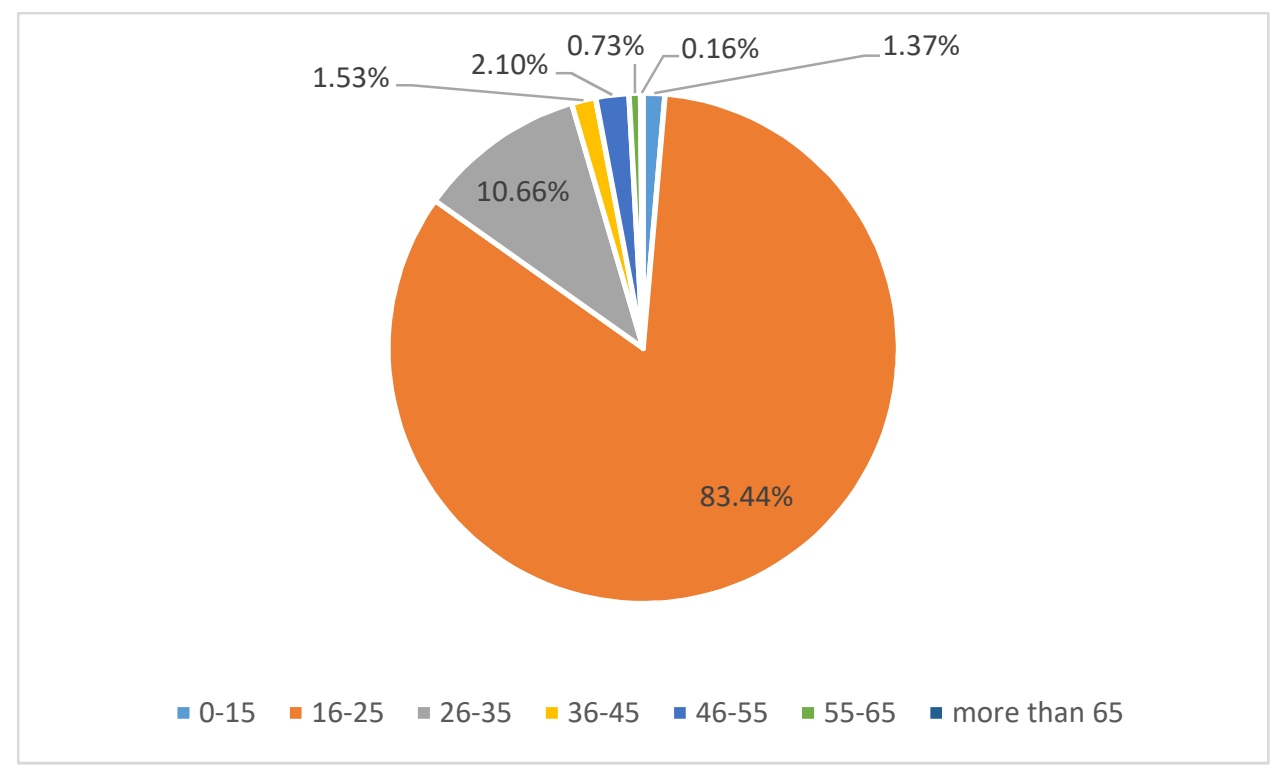

Figure 1. Age of respondents to the survey.

Considering the focus of the paper, the following analysis will be based on the questions related to sustainable fashion (H1, H2, H3) and the circular economy (DRQ1). According to the fact that the number of people buying ethical clothes is increasing, but still represents a niche market [95], respondents were asked to think about shopping ethically and give, according to their personal values, more or less importance to various aspects of sustainability practices; as we can see in the next graph (Figure 2), basically, those aspects were equally important for the respondents.

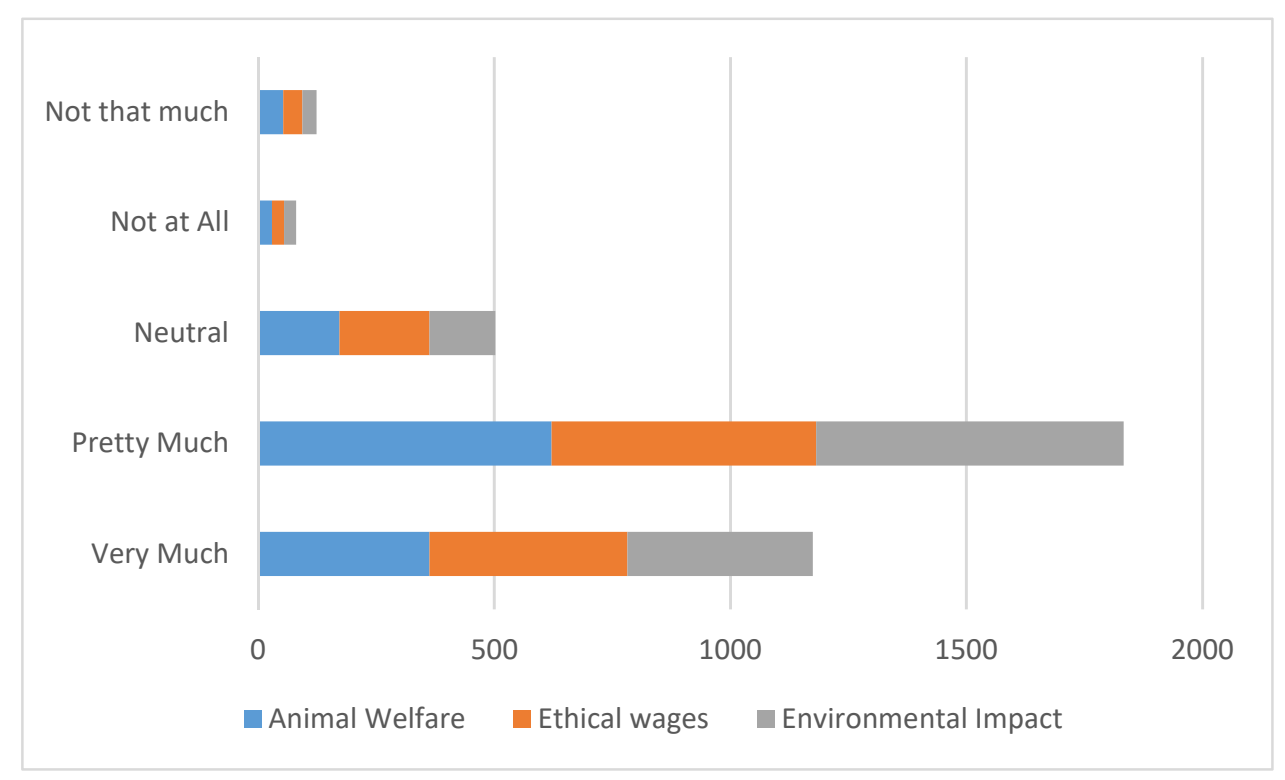

Figure 2. Sustainability aspects.

As previously analyzed, the literature highlighted three trends that were taken as the basis for the quantitative analysis. Starting from this point, an index of sustainability was elaborated made by the values, derived from the sample, regarding the aspects of the concepts of animal welfare, ethical 
wages, and the impact on the environment. Consequently, we introduced a response mean index for testing our hypotheses. Using the values derived from the survey related to the importance of sustainable fashion, we investigated the first hypothesis object $(\mathrm{H} 1)$. $\mathrm{H} 1$ potentially verifies if the answers provided a gender difference between males and females belonging to Generation $\mathrm{Z}$, in order to understand if the importance of sustainability principles in fashion is, overall, equal or not between these two groups. The results are shown in Tables 1-3:

Table 1. Z-test sustainability fashion index.

\begin{tabular}{cc}
\hline Data & Value \\
\hline Sustainability Fashion Index Female (Mean) & 3.37 \\
Sustainability Fashion Index Male (Mean) & 2.91 \\
Variance of the Females & 0.43 \\
Variance of the Males & 0.87 \\
Number of Females & 750 \\
Number of Males & 283 \\
\hline
\end{tabular}

Table 2. Chi-squared test sustainability in fashion (sectorial).

\begin{tabular}{|c|c|c|c|c|c|c|}
\hline \multirow{2}{*}{$\begin{array}{c}\text { Evaluation of } \\
\text { Sustainability in Fashion } \\
\text { Per Sector }\end{array}$} & \multicolumn{2}{|c|}{ Ethical Wage } & \multicolumn{2}{|c|}{ Animal Welfare } & \multicolumn{2}{|c|}{ Environment } \\
\hline & Female & Male & Female & Male & Female & Male \\
\hline 0 & 3 & 18 & 6 & 14 & 4 & 13 \\
\hline 1 & 20 & 16 & 16 & 20 & 14 & 9 \\
\hline 2 & 95 & 62 & 76 & 66 & 80 & 38 \\
\hline 3 & 252 & 98 & 218 & 92 & 249 & 90 \\
\hline 4 & 380 & 89 & 434 & 91 & 403 & 133 \\
\hline Test & \multicolumn{2}{|c|}{$\begin{array}{c}\text { X-squared }=69.492 \\
\text { df }=4\end{array}$} & \multicolumn{2}{|c|}{$\begin{array}{c}\text { X-squared }=86.137 \\
\mathrm{df}=4\end{array}$} & \multicolumn{2}{|c|}{$\begin{array}{c}\text { X-squared }=25.466 \\
\mathrm{df}=4\end{array}$} \\
\hline$p$-value & \multicolumn{2}{|c|}{$p$-value $<0.001$} & \multicolumn{2}{|c|}{$p$-value $<0.001$} & \multicolumn{2}{|c|}{$p$-value $<0.001$} \\
\hline
\end{tabular}

Table 3. Generation differences in fashion sustainability.

\begin{tabular}{cccc}
\hline Generation Z & \multicolumn{2}{c}{ People $>$ 26 Y.o. } \\
\hline Mean of the sustainability Fashion Index & 3.24 & Mean of the sustainability Fashion Index & 3.17 \\
Variance & 0.59 & Variance & 0.78 \\
Sample numerosity & 1033 & Sample numerosity & 188 \\
\hline
\end{tabular}

Assuming the normality of the data, a Z-test was elaborated for analyzing the mean most significant differences between female and male, with a result of 7.63, with a $p$-value of 0.001 . The results of the questionnaire support H1. In fact, considering the three fashion categories taken into account, gender seems to be relevant regarding the role of sustainability in fashion, as the female category was more sustainable in fashion than male.

The three index categories are represented, from a descriptive point of view, in the following graph (Figure 3).

Considering the three categories of the index, for testing H2, a Pearson's Chi-squared test was used.

The previous table shows the results of the tests. The results of the survey completely support H2. In fact, gender difference (for Generation Z) seems to be relevant also for the three categories separately analyzed. It was possible to affirm that there was a statistically significant gender difference, and for this reason, $\mathrm{H} 2$ was accepted. The aspect investigated in $\mathrm{H} 3$ is if the sustainability fashion index presents some differences between different generations. It is important to remark that, for this hypothesis, two groups were created: Generation $\mathrm{Z}$ and people that are more than 26 years old. 


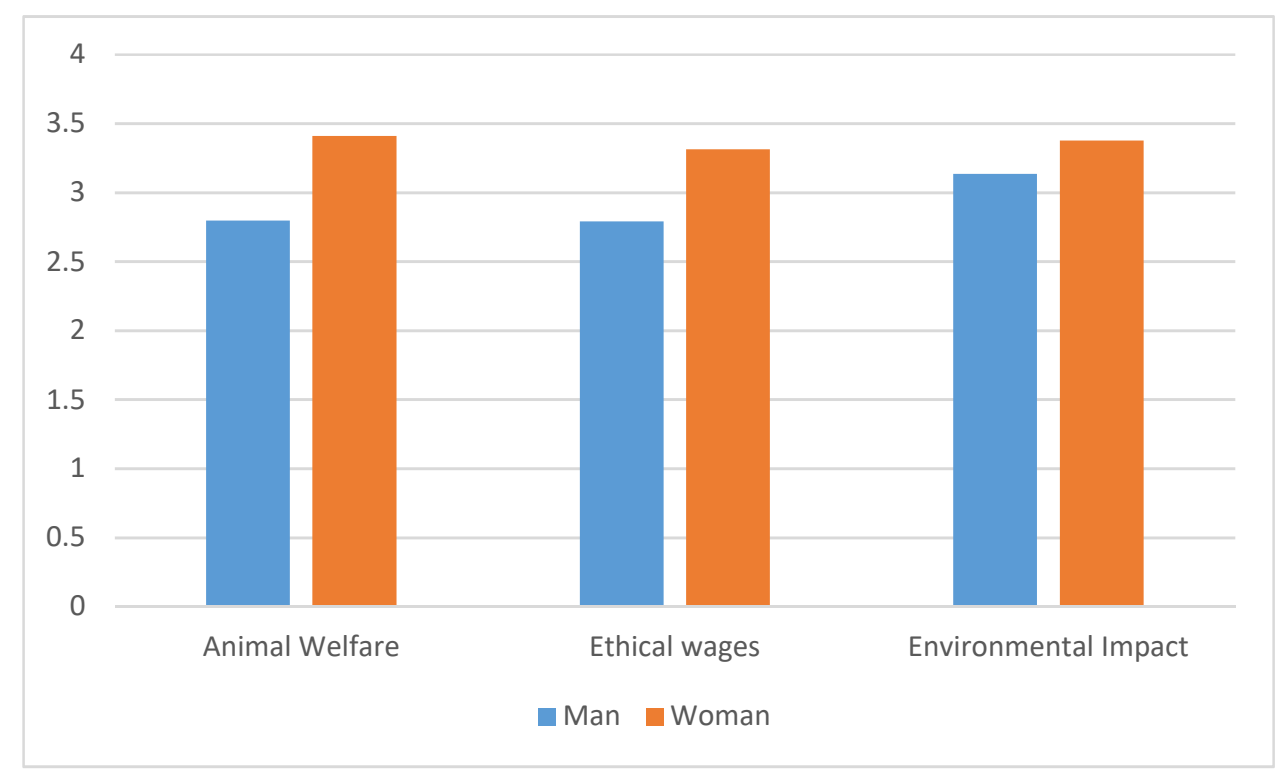

Figure 3. Gender difference in fashion sustainability.

Assuming the normality of the data, a Z-test was elaborated for the mean difference between Generation $Z$ and people who were more than 26 years old, which had a result of 1.04 with a $p$-value bigger than 0.1; for this reason, $\mathrm{H} 3$ was refused. There was no evidence that between these two groups, the level of sustainable fashion was similar. This is a surprising result due to the fact that, according to the literature, there is a positive relationship between age and the attention to sustainability principles. In this case, probably, the result was partially influenced by the sample composition.

Regarding DRQ1, as aforementioned in the previous theoretical paragraph, circular economy is getting more and more important in order to produce sustainable garments in the future, in which a growth of the global population is forecast. In the survey there was a section completely dedicated to this topic, with questions related to the consumer's motivation behind buying used clothes or discarding personal dresses. For the analysis of these questions the entire sample of respondents was taken into consideration. The first question was linked to the concept of discarding a dress, the following graph (Figure 4) summarizes the main motivations emerging from the survey.

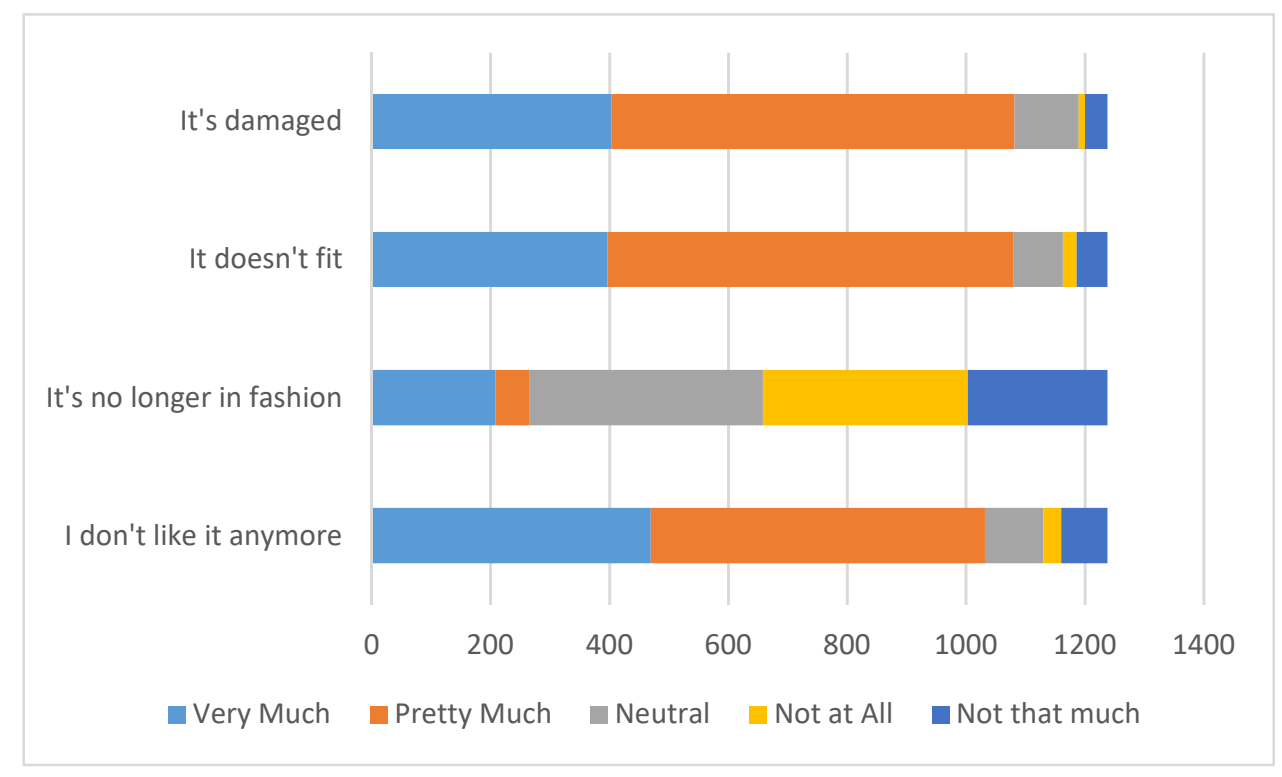

Figure 4. How important are the following aspects to make you decide to discard a dress? 
The results of the survey show that three of the four alternatives had mainly the same percentage of results (considering the value of "Very Much" and "Pretty Much"). Damage, fitting problems, and preferences showed the same trend and it is possible to affirm that, for the sample analyzed, these contribute in the same way to the discarding process. Considering fashion and trends, the breakdown of responses was different. A relevant part of the sample affirmed that they do not agree with this statement, this answer was certainly influenced by the composition of the respondents (who were mainly students and young people). Another item of the survey was related to the opportunity to give a "second chance" to personal clothes. On this question, respondents declared to usually bring clothes to charity shops or give them to friends or family members. This is an important aspect for creating circular economy, but from the answers it also emerged that respondents do not often consider repairing clothes or reinventing them. This can be explained by the fact that, considering the sample composition, it is possible to think that respondents usually buy low prices for one item and they do not have the technical skills to repair it by themselves. Another reason is the fact that fashion tendencies are changing very fast, as explained earlier (Figure 5).

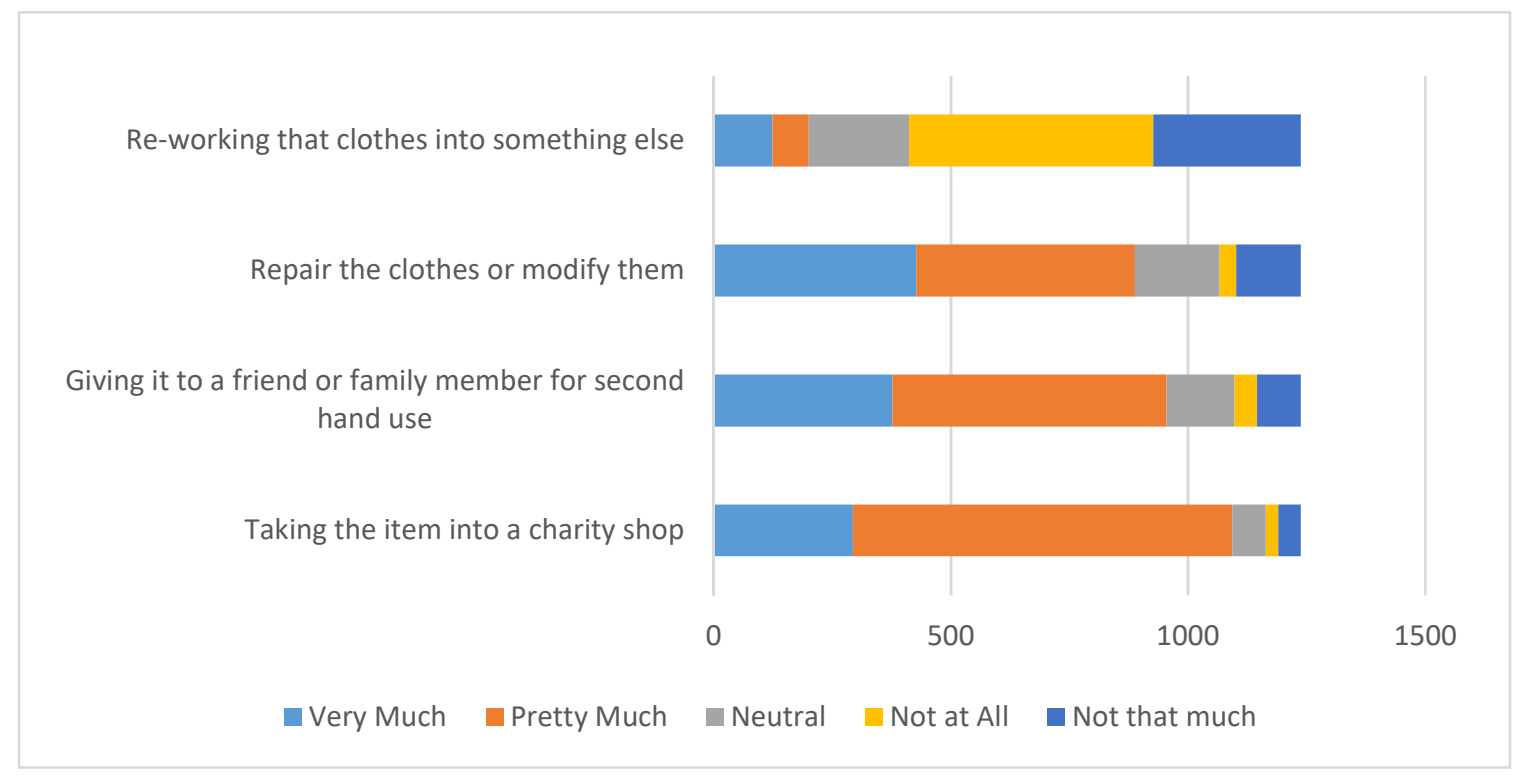

Figure 5. Before throwing clothes away, would you consider it important to do one of the following actions?

The last element related to the circular economy was related to the frequency of purchase of clothing in second-hand stores.

The previous graph (Figure 6) shows that the majority of respondents can afford to buy new clothes instead of used ones (in terms of economic possibilities). This last question shows how people are not likely to buy from second-hand stores, for two main reasons $[96,97]$ :

1. Buying form second-hand stores in the Italian culture is a practice made usually by people who cannot economically afford to buy new clothes;

2. Used clothes are often not in line with current fashion tendencies.

In fact, in Western countries, the "second-hand fashion market" is still just a niche market in which customers are mainly poor people and a very small percentage of people who just buy items there because they believe in circular economy as a real sustainable practice. The world's largest importers of used clothing are Sub-Saharan countries, receiving over 25\% of global second-hand clothing exports [98]. 


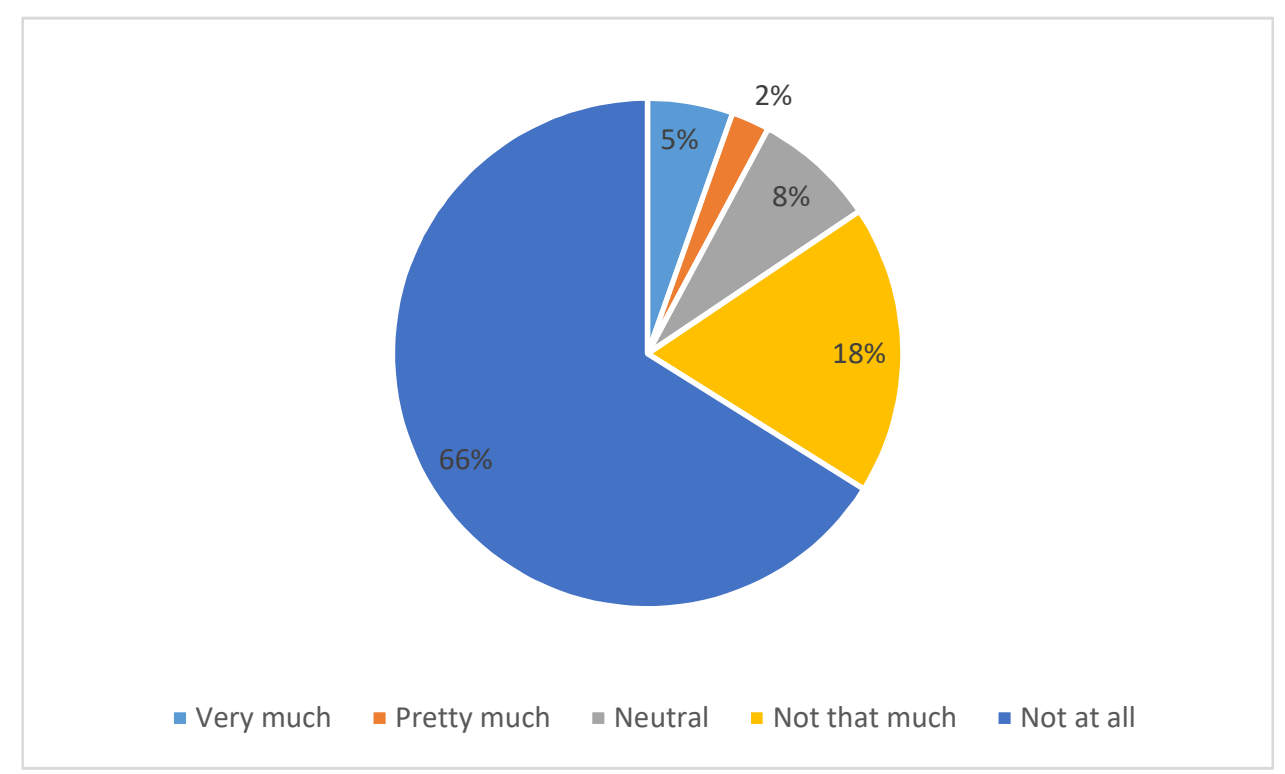

Figure 6. Frequency of purchase in second-hand stores.

\section{Discussion and Conclusions}

After analyzing the main fashion trends from 2016 to the present, it is possible to highlight those destined to persist in the coming years: the adoption of sustainability practices among fashion players, attention to the sustainability of the entire value chain, continuous improvement of customer service provided by digital platforms, increased automation of production processes. In recent years, more and more attention has been paid to the issues of environmental sustainability by Governments, consumers, and companies. The textile sector has been the subject of heavy criticism connected to its environmental impacts and human health arising from residues of substances on products and production processes associated with it. Attention to the ecological dimension is expressed in reducing the waste of natural resources, reducing production costs, reducing global warming, and paying attention to the consequences of overpopulation, containing the toxicity of certain industrial products, and reducing air and water pollution. According to the analyses carried out, a positive trend clearly emerged for the future; the answers provided by respondents represent hope for an increase in the ethical approaches to business and in the adoption of sustainable strategies and practices in the fashion industry. The results are strictly consistent with the literature related to the topic analyzed in the paper; in fact, considering Generation $\mathrm{Z}$ as a benchmark (due to the number of respondents which composed the sample), it was analyzed how, based on a gender classification, the answers related to these topics present differences. The sample clearly showed a preponderance of the role assigned to sustainability in fashion by female respondents. Much more interesting, and partially divergent from the literature, is the non-difference within the sample between Generation $Z$ and people older than 26 years old. This result could be determined by the composition of the sample (see the paragraph "Limitations of the Research and Future Developments") even if, for the central limit theorem, a number equal to 188 is largely sufficient to approximate the data to a normal distribution. Considering the role of the circular economy, fashion companies can implement a circular policy by choosing the most suitable business model. It is important not to forget the importance of the design of fashion product that can be disassembled, the conception of the product as a service, the use of available resources, the recovery, reuse, and extension of the product life cycle. According to the respondents, as previously discussed, the decision-making process to discard a dress is mainly based on concrete issues and personal tastes, and they consider fashion as a less important element. Considering the aspect of solidarity, it emerged that over 1000 respondents (which represented more than $80 \%$ of the sample) were inclined to leave their used clothes to voluntary associations/churches. This is a favorable point 
for the development, in solidarity, of this kind of economy. Finally, it seems that the purchase of used clothes is not interesting for the respondents; this result was certainly influenced by the economic condition and Italian cultural background, which is very different from other countries such as India or Vietnam, where this practice is well diffused [64,99].

The survey highlighted the growing attention that the younger generations today are paying to sustainability and circular economy, which leads to the conclusion that for the fashion market these factors are becoming a strategic element of great importance and a source of long-lasting competitive advantage. The increased sensitivity of consumers toward the questions correlated to sustainability causes fashion brands to improve their reputation by encompassing social responsibility in their value proposal.

The changed competitive context in which companies find themselves operating inevitably leads sustainability to become a powerful driver of innovation. This perspective, in a phase of growing affirmation, reflects the need for fashion companies to redirect their strategic approach toward transforming social responsibility and sustainability into a competitive opportunity to benefit both the individual companies and the overall sector. These trends open interesting research opportunities under the profile of the analysis of strategic behavior and emerging new business models in this sector, even today barely investigated by management literature. In this sense, the present study aimed to offer a first, albeit embryonic, innovative contribution to management studies on a topic currently little investigated by the literature.

\section{Limitations of the Research and Future Developments}

Finally, our results are subject to certain research limitations, firstly due to the digital tools employed. The concept of a standardized survey administered only online certainly limited the participation of a relevant number of older generations. Nonetheless, the primary respondents, due to the age, were students or young people. For this reason, the analyzed sample was unbalanced and it forced us to focus most of the analysis on the so-called Generation Z, influencing our conclusions. A clear limitation of this paper, as briefly explained in Section 5, was the part of sample used for H3. It is clear to all authors that the numerical differences between Generation $Z$ and the rest of the sample are relevant. We can only underline, however, according to the central limit theorem (concerning the normality of the data), that the numerosity was greater than 120 . For this reason, we believe that the results of this test can, however, be considered as quite consistent.

Therefore, future research should focus on increasing the respondent sample size using different means of communication, not only via social network and internet, to define this phenomenon in a wider way, considering also other parts of the population. From a geographical point of view, it will be possible to make some comparison with the concept of fashion industry and circular economy with samples from other countries, paying attention to their representativeness.

Author Contributions: Conceptualization, P.G. and E.P.; methodology, P.G. and E.P.; validation, P.G., E.P. and D.G.; formal analysis, D.G.; resources, P.G. and R.P.; data curation, P.G. and D.G.; writing—original draft preparation, E.P. and D.G.; writing-review and editing, P.G. and R.P.; funding acquisition, P.G. and R.P. All authors have read and agreed to the published version of the manuscript.

Funding: This research received no external funding.

Acknowledgments: The empirical findings discussed in the paper are the results of the 2019 Edition of The International Practicum Project launched by the Department of Economics of the University of Insubria for promoting cross-cultural educational entrepreneurship, who involved students from Georgia, Moldova and Italy. The Project has benefited from a financial support both from the European Commission within the Erasmus+ Project Call 2018 IT02-KA107-047891 and from the University of Insubria.

Conflicts of Interest: The authors declare no conflict of interest. 


\section{References}

1. BOF \& McKinsey. The State of Fashion Report 2019. Available online: https://www.businessoffashion.com/ articles/intelligence/the-state-of-fashion-2019 (accessed on 26 February 2020).

2. BCG. Luxury Market Trends-Digital \& Experiential Luxury 2019. Available online: http://media-publications.bcg.com/france/True-Luxury\%20Global\%20Consumer\%20Insight\%202019\% 20-\%20Plenary\%20-\%20vMedia.pdf (accessed on 26 February 2020).

3. Kotler, P.; Kartajaya, H.; Setiawan, I. Marketing 4.0. Moving from Traditional to Digital; Wiley \& Sons Inc.: Hoboken, NJ, USA, 2017.

4. Mulhern, F. Integrated marketing communications: From media channels to digital connectivity. J. Mark. Commun. 2009, 15, 85-101. [CrossRef]

5. Lee, I. The Internet of Things in the Modern Business Environment; IGI Global: Hershey, PA, USA, 2017.

6. Kline, S.; Dyer-Witheford, N.; de Peuter, G. Digital Play: The Interaction of Technology, Culture, and Marketing; McGill Queen's University Press: Montreal, QC, Canada, 2003.

7. Hofmann, E.; Rüsch, M. Industry 4.0 and the current status as well as future prospects on logistics. Comput. Ind. 2017, 89, 23-34.

8. Bottinelli, L.; Pavione, E. Distretti Industriali e Cluster Tecnologici: Strategie Emergenti di Valorizzazione Della ricerca e dell'Innovazione; Giuffrè ediItore: Milano, Italy, 2011.

9. Burns, L.; Mullet, K.; Bryant, N. The Business of Fashion: Designing, Manufacturing, and Marketing, 5th ed.; Bloomsbury Publishing Inc.: New York, NY, USA, 2016.

10. Hines, T.; Bruce, M. Fashion Marketing; Elsevier Ltd.: Alpharetta, GA, USA, 2017.

11. Pavione, E.; Pezzetti, R.; Dall'Ava, M. Emerging Competitive Strategies in the Global Luxury Industry in the Perspective of Sustainable Development: The Case of Kering Group. Manag. Dyn. Knowl. Econ. 2016, 4, 241-261.

12. Chung, Y.; Kim, A.J. Effects of mergers and acquisitions on brand loyalty in luxury Brands: The moderating roles of luxury tier difference and social media. J. Bus. Res. 2019. Early View. [CrossRef]

13. Kankanamge, P.; Dinesha, C. Influence of Culture on Consumer Behavior in the Fashion Industry. Master's Thesis, University of Agder, Kristiansand S, Norway, 2014.

14. Rath, P.; Bay, S. The Why of the Buy. Consumer Behavior and Fashion Marketing; Bloomsbury Publishing Inc.: New York, NY, USA, 2015.

15. Gazzola, P.; Grechi, D.; Ossola, P.; Pavione, E. Certified Benefit Corporations as a new way to make sustainable business: The Italian example. Corp. Soc. Responsib. Environ. Manag. 2019, 26, 1435-1445. [CrossRef]

16. Gazzola, P.; Pavione, E.; Grechi, D.; Ossola, P. Cycle tourism as a driver for the sustainable development of little-known or remote territories: The experience of the Apennine regions of Northern Italy. Sustainability 2018, 10, 1863. [CrossRef]

17. Bhardwaj, V.; Fairhurst, A. Fast fashion: Response to changes in the fashion industry. The International Review of Retail. Distrib. Consum. Res. 2010, 20, 165-173. [CrossRef]

18. Gabrielli, V.; Baghi, I.; Codeluppi, V. Consumption practices of fast fashion products: A consumer-based approach. J. Fash. Mark. Manag. 2013, 17, 206-224. [CrossRef]

19. Pantano, E.; Giglio, S.; Dennis, C. Making sense of consumers' tweets: Sentiment outcomes for fast fashion retailers through Big Data analytics. Int. J. Retail. Distrib. Manag. 2019, 47, 915-927. [CrossRef]

20. Zou, X.; Wong, W.; Gao, C.; Zhou, J. FoCo system: A tool to bridge the domain gap between fashion and artificial intelligence. Int. J. Cloth. Sci. Technol. 2019, 31, 630-643. [CrossRef]

21. Bendoni, W. Social Media for Fashion Marketing; Bloomsbury Publishing Inc.: New York, NY, USA, 2017.

22. Kaplan, A.; Haenlein, M. Users of the world, unite! The challenges and opportunities of Social Media. Bus. Horiz. 2010, 53, 59-68. [CrossRef]

23. Shankar, V.; Kleijnen, M.; Ramanathan, S.; Rizley, R.; Holland, S.; Morrisey, S. Mobile Shopper Marketing: Key Issues, Current Insights, and Future Research Avenues. J. Interact. Mark. 2016, 34, 37-48. [CrossRef]

24. Sułkowski, Ł.; Kaczorowska-Spychalska, D. Social Media in the Process of Marketing Evolution in Polish Textile-Clothing Industry. Fibres Text. East. Eur. 2016, 5, 15-20.

25. Jin, S.; Muqaddam, A.; Ryu, E. Instafamous and social media influencer marketing. Mark. Intell. Plan. 2019, 37, 567-579. [CrossRef] 
26. Elishar-Malka, V.; Ariel, Y.; Avidar, R. A story of love and hate: Smartphones in students' lives. In Mediated Millennials; Emerald Publishing Limited: Bingley, UK, 2015.

27. Meen, T.; Shen, S. People and their smartphones-Mapping mobile interaction in the modern connected world. Eng. Comput. 2016, 33, 1642-1658.

28. Kim, J. Luxury fashion goods ownership and collecting behavior in an omni-channel retail environment: Empirical findings from affluent consumers in the US. Res. J. Text. Appar. 2019, 23, 212-231. [CrossRef]

29. Lang, C.; Seo, S.; Liu, C. Motivations and obstacles for fashion renting: A cross-cultural comparison. J. Fash. Mark. Manag. 2019, 23, 519-536. [CrossRef]

30. Spaargaren, G. Sustainable consumption: A theoretical and environmental policy perspective. Soc. Nat. Resour. 2003, 16, 687-701. [CrossRef]

31. Kant Hvass, K.; Pedersen, E. Toward circular economy of fashion: Experiences from a brand's product take-back initiative. J. Fash. Mark. Manag. 2019, 23, 345-365. [CrossRef]

32. McHattie, L.S.; Ballie, J. Material futures: Design-led approaches to crafting conversations in the circular economy. J. Text. Des. Res. Pract. 2018, 6, 184-200. [CrossRef]

33. Stern, P.C. Contributions of psychology to limiting climate change. Am. Psychol. 2011, 66, 303-314. [CrossRef] [PubMed]

34. Griggs, D.; Stafford-Smith, M.; Gaffney, O.; Rockström, J.; Öhman, M.C.; Shyamsundar, P.; Noble, I. Policy: Sustainable development goals for people and planet. Nature 2013, 495, 305-307. [CrossRef] [PubMed]

35. Lee, B.X.; Kjaerulf, F.; Turner, S.; Cohen, L.; Donnelly, P.D.; Muggah, R.; Waller, I. Transforming our world: Implementing the 2030 agenda through sustainable development goal indicators. J. Public Health Policy 2016, 37, 13-31. [CrossRef] [PubMed]

36. Doyle, M.W.; Stiglitz, J.E. Eliminating extreme inequality: A sustainable development goal, 2015-2030. Ethics Int. Aff. 2014, 28, 5-13. [CrossRef]

37. Hák, T.; Janoušková, S.; Moldan, B. Sustainable Development Goals: A need for relevant indicators. Ecol. Indic. 2016, 60, 565-573. [CrossRef]

38. Leal Filho, W.; Azeiteiro, U.; Alves, F.; Pace, P.; Mifsud, M.; Brandli, L.; Disterheft, A. Reinvigorating the sustainable development research agenda: The role of the sustainable development goals (SDG). Int. J. Sustain. Dev. World Ecol. 2018, 25, 131-142. [CrossRef]

39. Ellen MacArthur Foundation. Towards the Circular Economy: An Economic and Business Rationale for an Accelerated Transition; Ellen MacArthur Foundation: Cowes, UK, 2013; Available online: https://www.ellenmacarthurfoundation.org/assets/downloads/publications/Ellen-MacArthurFoundation-Towards-the-Circular-Economy-vol.1.pdf (accessed on 26 February 2020).

40. Birkie, S.; Feldmann, A.; Nuur, C.; Korhonen, J. Circular economy as an essential contested concept. J. Clean. Prod. 2017, 175, 544-552.

41. Ruiz-Real, J.L.; Uribe-Toril, J.; De Pablo Valenciano, J.; Gázquez-Abad, J.C. Worldwide research on circular economy and environment: A bibliometric analysis. Int. J. Environ. Res. Public Health 2018, 15, 2699. [CrossRef]

42. Ruiz-Real, J.L.; Uribe-Toril, J.; Gázquez-Abad, J.C.; de Pablo Valenciano, J. Sustainability and Retail: Analysis of Global Research. Sustainability 2019, 11, 14. [CrossRef]

43. Blomsma, F.; Brennan, G. The emergence of circular economy: A new framing around prolonging resource productivity. J. Ind. Ecol. 2017, 21, 603-614. [CrossRef]

44. Pomponi, F.; Moncaster, A. Circular economy for the built environment: A research framework. J. Clean. Prod. 2017, 143, 710-718. [CrossRef]

45. Lieder, M.; Rashid, A. Towards circular economy implementation: A comprehensive review in context of manufacturing industry. J. Clean. Prod. 2016, 115, 36-51. [CrossRef]

46. Geissdoerfer, M.; Savaget, P.; Bocken, N.; Hultink, E.J. The circular economy-A new sustainability paradigm? J. Clean. Prod. 2017, 143, 757-768. [CrossRef]

47. Dryzek, J.S. The Politics of the Earth: Environmental Discourses; Oxford University Press: Oxford, UK, 2013.

48. Commoner, B. The Closing Circle: Nature, Man, and Technology; Dover Publications Inc.: Mineola, NY, USA, 1971; pp. 11-44.

49. Reday, G.; Stahel, W.R. Potential for Substituting Manpower for Energy; Battelle Memorial Institute: Columbus, $\mathrm{OH}, \mathrm{USA}, 1976$.

50. Jacometti, V. Circular Economy and Waste in the Fashion Industry. Laws 2019, 8, 27. [CrossRef] 
51. Intelligent Assets: Unlocking the Circular Economy Potential. Ellen MacArthur Foundation. Available online: https://www.ellenmacarthurfoundation.org/assets/downloads/publications/EllenMacArthurFoundation Intelligent_Assets_080216-AUDIO-E.pdf (accessed on 26 February 2020).

52. Stahel, W.R. The circular economy. Nature 2016, 531, 435-438. [CrossRef]

53. Raworth, K. Doughnut Economics: Seven Ways to Think Like a 21st-Century Economist; Chelsea Green Publishing: White River Junction, VT, USA, 2017.

54. Pradhan, P.; Costa, L.; Rybski, D.; Lucht, W.; Kropp, J.P. A systematic study of Sustainable Development Goal (SDG) interactions. Earth's Future 2017, 5, 1169-1179. [CrossRef]

55. Jung, S.; Jin, B. Sustainable Development of Slow Fashion Businesses: Customer Value Approach. Sustainability 2016, 8, 540. [CrossRef]

56. Grant, J. The Green Marketing Manifesto; Franco Brioschi Editore: Milano, Italy, 2009.

57. Grechi, D.; Ossola, P.; Pavione, E. Expo 2015 and development of slow tourism: Are the tourism product clubs in the territory of Varese successful? In Proceedings of the Toulon-Verona Conference "Excellence in Services", Palermo, Italy, 31 August-1 September 2015; pp. 227-242.

58. Kapferer, J.N.; Michaut-Denizeau, A. Is luxury compatible with sustainability? Luxury consumers' viewpoint. J. Brand Manag. 2014, 21, 1-22. [CrossRef]

59. Joy, A.; Sherry, J.F., Jr.; Venkatesh, A.; Wang, J.; Chan, R. Fast fashion, sustainability, and the ethical appeal of luxury brands. Fash. Theory 2012, 16, 273-295. [CrossRef]

60. Ki, C.W.; Kim, Y.K. Sustainable versus conspicuous luxury fashion purchase: Applying self-determination theory. Fam. Consum. Sci. Res. J. 2016, 44, 309-323. [CrossRef]

61. Hoffmann, J.; Coste-Maniere, I. Luxury Strategy in Action; Palgrave Macmillan: New York, NY, USA, 2012.

62. Zhang, M.; Kong, X.X.; Ramu, S.C. The transformation of the clothing industry in China. Asia Pac. Bus. Rev. 2016, 22, 86-109. [CrossRef]

63. Broda, J.; Przybyło, S.; Gawłowski, A.; Grzybowska-Pietras, J.; Sarna, E.; Rom, M.; Laszczak, R. Utilisation of textile wastes for the production of geotextiles designed for erosion protection. J. Text. Inst. 2019, 110, 435-444. [CrossRef]

64. Cuc, S.; Vidovic, M. Environmental sustainability through clothing recycling. Oper. Supply Chain Manag. 2011, 4, 108-115. [CrossRef]

65. Brooks, A.; Simon, D. Unravelling the Relationships between Used-Clothing Imports and the Decline of African Clothing Industries. Dev. Chang. 2012, 43, 1265-1290. [CrossRef]

66. Deloitte. Global Power of Luxury Goods 2019. Available online: https://www2.deloitte.com/it/it/pages/ about-deloitte/forms/deloitte-global-powers-luxury-goods-2019---form-registrazione.html (accessed on 26 February 2020).

67. McCrindle, M.; Wolfinger, E. The ABC of XYZ: Understanding the Global Generations; University of New South Wales: Sydney, Australia, 2009.

68. Meister, J.C.; Willyerd, K. Are You Ready to Manage Five Generations of Workers; Harvard Business Review: Boston, MA, USA, 2009.

69. Lissitsa, S.; Kol, O. Generation X vs. Generation Y-A decade of online shopping. J. Retail. Consum. Serv. 2016, 31, 304-312. [CrossRef]

70. Desy, J.R.; Reed, D.A.; Wolanskyj, A.P. Milestones and millennials: A perfect pairing-competency-based medical education and the learning preferences of Generation, Y. In Mayo Clinic Proceedings; Elsevier: Amsterdam, The Netherlands, 2017; pp. 243-250.

71. Cameron, E.A.; Pagnattaro, M.A. Beyond millennials: Engaging generation Z in business law classes. J. Leg. Stud. Educ. 2017, 34, 317-324. [CrossRef]

72. Bencsik, A.; Horváth-Csikós, G.; Juhász, T. Y and Z Generations at Workplaces. J. Compet. 2016, 8, 90-106. [CrossRef]

73. Sahin, E.; Ertepinar, H.; Teksoz, G. University Students' Behaviors Pertaining to Sustainability: A Structural Equation Model with Sustainability-Related Attributes. Int. J. Environ. Sci. Educ. 2012, 7, 459-478.

74. Toppinen, A.; Toivonen, R.; Valkeapää, A.; Rämö, A.K. Consumer perceptions of environmental and social sustainability of wood products in the Finnish market. Scand. J. For. Res. 2013, 28, 775-783. [CrossRef]

75. Grunert, K.G.; Hieke, S.; Wills, J. Sustainability labels on food products: Consumer motivation, understanding and use. Food Policy 2014, 44, 177-189. [CrossRef] 
76. Ben-Amar, W.; Chang, M.; McIlkenny, P. Board gender diversity and corporate response to sustainability initiatives: Evidence from the carbon disclosure project. J. Bus. Ethics 2017, 142, 369-383. [CrossRef]

77. Hwang, J.; Choi, J.K. An investigation of passengers' psychological benefits from green brands in an environmentally friendly airline context: The moderating role of gender. Sustainability 2018, 10, 80. [CrossRef]

78. Obermiller, C.; Isaac, M.S. Are Green Men from Venus? J. Manag. Glob. Sustain. 2018, 6, 45-66. [CrossRef]

79. Brough, A.R.; Wilkie, J.E.; Ma, J.; Isaac, M.S.; Gal, D. Is eco-friendly unmanly? The green-feminine stereotype and its effect on sustainable consumption. J. Consum. Res. 2016, 43, 567-582. [CrossRef]

80. PwC Report Millennials vs Generation Z. 2018. Available online: https://www.pwc.com/it/it/press-room/ assets/docs/cs_pwc_food.pdf (accessed on 27 February 2020).

81. Xuejie, C.; Chang, Q.; GuangHao, Z. Research on innovation supply chain management in fast fashion industry-A comparative analysis of ZARA and H\&M. In Proceedings of the 3rd International Conference on Education, Culture and Social Development (ICECSD 2019), Guangxi, China, 29-30 August 2019; Atlantis Press: Beijng, China, 2019; pp. 7-16.

82. Kapferer, J.N.; Michaut, A. Are Millennials really redefining luxury? A cross-generational analysis of perceptions of luxury from six countries. J. Brand Strategy 2019, 8, 250-264.

83. Brun, A.; Karaosman, H. Sustainability in the Luxury Fashion Supply Chain: Millennials' Perception. Marche Organ. 2020, 99-121. [CrossRef]

84. Harris, S.M. Development of the perceptions of mentoring relationships survey: A mixed methods approach. Int. J. Mult. Res. Approaches 2013, 7, 83-95. [CrossRef]

85. Koskey, K.L.; Stewart, V.C. A concurrent mixed methods approach to examining the quantitative and qualitative meaningfulness of absolute magnitude estimation scales in survey research. J. Mix. Methods Res. 2014, 8, 180-202. [CrossRef]

86. Boone, H.N.; Boone, D.A. Analyzing likert data. J. Ext. 2012, 50, 1-5.

87. Gazzola, P.; Pavione, E.; Dall'Ava, M. I differenti significati di sostenibilità per le aziende del lusso e della moda: Case studies a confronto. Econ. Aziend. Online 2020, 10, 663-676.

88. Hur, E.; Cassidy, T. Perceptions and attitudes towards sustainable fashion design: Challenges and opportunities for implementing sustainability in fashion. Int. J. Fash. Des. Technol. Educ. 2019, 12, 208-217. [CrossRef]

89. Ciasullo, M.V.; Maione, G.; Torre, C.; Troisi, O. What about sustainability? An empirical analysis of consumers' purchasing behavior in fashion context. Sustainability 2020, 9, 1617. [CrossRef]

90. Zenga, M. Lezioni di Statistica Descrittiva, 2nd ed.; G Giappichelli Editore: Turin, Italy, 2014.

91. Agresti, A.; Finlay, B.; Porcu, M. Statistica per le Scienze Sociali; Pearson: London, UK, 2009.

92. Paruolo, P. Elementi di Statistica; Carocci: Bologna, Italy, 1999.

93. Pauli, F.; Torelli, N.; Trevisani, M. Statistica: Esercizi ed Esempi; Pearson Italia Spa: Milano, Italy, 2008.

94. Faliva, M.; Zoia, M.G. Econometric profiles of testing of statistical hypotheses: Model specification tests. Statistica 2004, 64, 257-269.

95. Thomas, S. Fashion Ethics; Routledge: Abingdon on Thames, UK, 2017.

96. Brooks, A. Clothing Poverty: The Hidden World of Fast Fashion and Second-Hand Clothes; Zed Books Ltd.: London, UK, 2019.

97. Nørup, N.; Pihl, K.; Damgaard, A.; Scheutz, C. Replacement rates for second-hand clothing and household textiles-A survey study from Malawi, Mozambique and Angola. J. Clean. Prod. 2019, 235, 1026-1036. [CrossRef]

98. Edbring, E.G.; Lehner, M.; Mont, O. Exploring consumer attitudes to alternative models of consumption: Motivations and barriers. J. Clean. Prod. 2016, 123, 5-15. [CrossRef]

99. Ofreneo, R.E. Development choices for Philippine textiles and garments in the post-MFA era. J. Contemp. Asia 2009, 39, 543-561. [CrossRef]

(C) 2020 by the authors. Licensee MDPI, Basel, Switzerland. This article is an open access article distributed under the terms and conditions of the Creative Commons Attribution (CC BY) license (http://creativecommons.org/licenses/by/4.0/). 